CZASOPISMO INŻYNIERII LĄDOWEJ, ŚRODOWISKA I ARCHITEKTURY JOURNAL OF CIVIL ENGINEERING, ENVIRONMENT AND ARCHITECTURE

JCEEA, t. XXXIV, z. 64 (4///17), październik-grudzień 2017, s. 51-58, DOI:10.7862/rb.2017.191

\author{
Marek URBANIK ${ }^{1}$ \\ Barbara TCHÓRZEWSKA-CIEŚLAK ${ }^{2}$
}

\title{
SELECTED ISSUES OF GAS SUPPLY SAFETY
}

\begin{abstract}
Safety of gas supply is considerably depended on failure occurrence. Gas networks constitute large assets of gas companies, therefore it is crucial for them to maintain safe and reliable functioning of gas infrastructure. The disaster caused by gas explosion may cause very large material and human losses. The presented approach can be used to describe the losses being a result of failure of gas network. It can provide information for assessing gas supply systems in regards to the costs and losses related to failure occurrence in gas pipes. The analysis was based on the operational data obtained from the operation of gas network.
\end{abstract}

Keywords: gas network, gas losses, gas network failure, gas network functioning

\section{Introduction}

The current technical progress influences the growing requirements for the safe operation of critical infrastructure, including the gas supply system [21].

According to the European Gas Pipeline Incident Data Group through the period of five years the average and total number of failures has consistently reduced over the years with the tendency to stabilization $[4,5]$. At the same time gas consumption has increased affecting the continuous development of gas pipelines, also the requirements of customers referred to the reliability of the operation of gas systems are growing [23, 24].

It should be emphasized that the discussed topics are important from the point of view of domestic customers, who are the most numerous group constituting $97 \%$ of the total group of recipients $[1,10]$. On the other hand, taken into account the quantity of the sold natural gas, most of it was purchased by industrial customers, as much as $62 \%$ of which were dominated by fuel companies, including chemical, refining, petrochemical and nitrogenous companies $[8,9,22]$.

Proper functioning of gas systems constitutes the important issue, as leakage of gas into the atmosphere during the failure creates a risk of explosion and

\footnotetext{
${ }^{1}$ Autor do korespondencji / corresponding author: Marek Urbanik, Politechnika Rzeszowska, al. Powstańców Warszawy 6, 35-959 Rzeszów, tel. 17 8651408, d314@stud.prz.edu.pl

${ }^{2}$ Barbara Tchórzewska-Cieślak, Politechnika Rzeszowska, al. Powstańców Warszawy 6, 35-959 Rzeszów, tel. 17 8651435, cbarbara@prz.edu.pl
} 
fire, by which accidental people or customers, as well as employees of gas plant, can be injured $[2,19,20,25]$.

Safety of gas supply should ensure stable supply at a level guaranteeing the recipient's needs and with the costs accepted by economy and society, assuming the optimal use of domestic energy resources and the diversification of gas supply sources [14, 1718$]$.

Therefore the current problems are associated with increasing safety of gas supplies, as well as minimizing the risks for the users and their protection during the operation of the gas system, as well as through new investments or modernization $[12,13]$.

The current energy policy is based on the project of the Polish Energy Policy until 2050, taking into account the provisions of the Directive 2009/73/EC of the European Parliament and the Council of 13 July 2009 concerning common rules for internal gas market and aims to provide the following issues: the diversification of sources of supply through diversification of supply, the stability of the political situation, as well as drawing attention to the geographical location of sources of supply, domestic or foreign [3]. Attention is also focused on fuel storage, ownership of energy sector companies and supply system, indication if it is state or commerce, supervision and regulation of the system by the state through scope and efficiency of supervision. The important issue is to control supply system condition, through transmission capacity, technical condition and reliability, which is associated with forecasting, planning, development and investment decisions [15].

Therefore in the paper the analysis concerning undesirable events occurring in gas supply system was performed, as well as the issues connected with failure of gas network were analysed.

\section{Case studies of undesirable events resulting from gas network failure}

Transport of natural gas by gas pipelines is one of the safest way of transport of this fuel. However, during this type of transport some failures occur, which sometimes have very serious consequences $[2,11]$. A particular threat is unsealing of the gas pipeline located in the ground, because of the location such a failure is noticed after a long time.

The most common causes of unsealing of the underground gas pipelines are [1]:

- splitting welds,

- mechanical damage, e.g. by an excavator bucket during construction work,

- unsealing of threaded connections,

- corrosion of gas pipelines,

- improper gas composition, which damages the gas pipeline from the inside. 
The fastest to be detected is pipeline leak caused by mechanical damage, because such a failure is immediately noticed by a perpetrator. Gas leaking from a gas pipeline into the ground can cause a number of negative effects, the size of which depends on the site of leak - it depends on the possibility of gas migration after leaving the pipeline and this, in turn, depends on the geological conditions and underground infrastructure next to the site of pipeline damage.

The typical negative effects of the underground gas pipeline unsealing include the destruction of vegetation (due to the negative impact of methane on the root system of the plants), a fire that can occur if gas gets outside through the slits in the ground. A particularly dangerous situation is when the gas from the underground gas pipeline enters the underground sewerage system, telecommunications infrastructure, etc. Through these channels gas can enter the buildings and, if not detected, can lead to poisoning people being there or, if gets the appropriate concentration, to explosion. Gas migrating from damaged pipeline to the buildings was often a cause of catastrophe even in the buildings without a gas installation.

The escaping natural gas from the damaged underground gas pipeline probably contributed to the gas explosion in a multi-family building in Pruszcz Gdański. It happened in January 2017. As a result of the gas explosion the top of the building collapsed, which caused that, according to the inspectors, further living in this building due to significant damage was not possible. There were no fatalities but one person was hospitalized. The building in which the explosion occurred was not connected to the gas network. Probably natural gas got to the building from the cracked weld of the gas pipeline running under the building.

In September 2013, in the village of Dormowo, the high pressure gas pipeline was unsealed. Due to the threat of gas explosion, 200 people living near the site of the failure were evacuated. The pipeline was damaged in the peat field. The blast caused by the gas outflow caused the nearby buildings to be covered with peat dust. The failure was detected by the sensors that monitor the pressure in the gas pipeline. As a result of the failure no one was injured and no fatalities occurred. A probable cause of failure were construction works performed along the damaged gas pipeline [6].

In Leszno, in July 2017, as a result of the gas pipeline unsealing the gas entered the sewers where it reached an explosive concentration. In order to minimize the likelihood of an explosion in the area, the electricity supply was turned of and 100 people were evacuated. The failure was reported at 10 p.m., the removal of the failure lasted until the morning and then the residents returned to their homes and the electricity supply was resumed [7].

The presented failures which happened recently were caused by unsealing of the gas pipeline. In the given examples, fortunately, there were no major losses, but, unfortunately, in the past there were some gas pipeline failures as 
a result of which the fatalities occurred. An example may be the year 2013 and unsealing of the high pressure gas pipeline as a result of construction works in Jankow Przygodzki. Two people were killed as a result of the failure, while thirteen people were injured, seven of them were hospitalized. As a result of the fire, ten residential buildings were completely burned down. At this moment, the biggest catastrophe associated with unsealing of the gas pipeline in Poland should be also mentioned. It was the natural gas explosion in the Rotunda PKO in Warsaw, which took place in February 1979. The failure occurred due to the rupture of the valve housing in the pipeline, causing leakage of gas to the ground, as a result of the low temperature there were slits in frozen ground by which gas escaped to the technical channels and further to the building. Upon reaching the explosive concentration, there was the explosion inside the building. It is worth mentioning, that the low temperature caused the condensation of the gas deodorizing agent, which made the gas odourless and difficult to be detected. It is also worth mentioning that the Rotunda building was not connected to the gas network. In this disaster 49 people were killed, 135 injured, 77 of them were hospitalized.

\section{Threat to the proper functioning of the gas network}

The result of pipeline unsealing is a leak of gas. If the escaping gas in the air reaches a suitable concentration and the ignition source exists (for example a spark), the ignition and then a fire or explosion occurs.

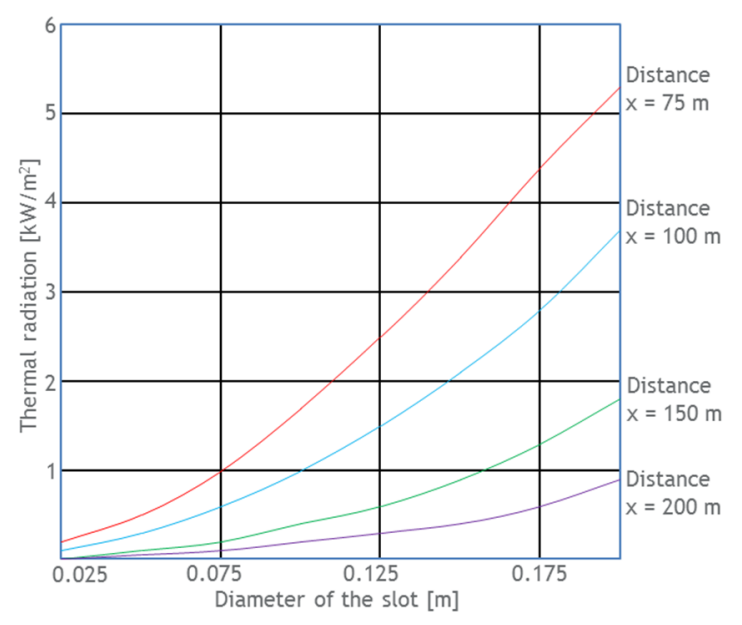

Fig. 1. Thermal radiation according to the diameter of silt in the gas pipeline at a pressure of $1.5 \mathrm{MPa}$, own work on the basis of [16]

Rys. 1. Promieniowanie cieplne w zależności od średnicy szczeliny dla gazociągu o ciśnieniu 1,5 MPa, opracowano na podstawie [16] 
An explosion will occur if combustion of gas appears almost simultaneously in the entire volume of the gas mixture with air. In such case, the effect is the shock wave, which will cause the greatest damage. However, not always a result of the gas leak is an explosion. If combustion takes place gradually there is a fire which causes the biggest damage through thermal radiation. In the Figure 1 the value of thermal radiation depending on the diameter of the slit in the gas pipeline where the gas pressure is $1.5 \mathrm{MPa}$ was presented.

It is obvious that the larger the gas leakage gap, the higher the thermal radiation value. At the same time, with the given gas leakage gap diameter and closer to the leakage source, the value of the thermal radiation increases. For example, for a gap of $0.175 \mathrm{~m}$ at a distance of 75 meters from the source of fire, the thermal radiation value is over $5 \mathrm{~kW} / \mathrm{m}^{2}$ and 200 meters from the combustion site the thermal radiation decreases by about $1 \mathrm{~kW} / \mathrm{m}^{2}$.

The pipelines run both in inhabited and non-inhabited areas. If gas leakage occurs in area inhabited by humans, it is obvious that the probability that a person will be in a zone of thermal effect of burning gas is high.

In the Figure 2 the percentage of fatalities according to the time of exposure and the diameter of the gap in the gas pipeline was shown.

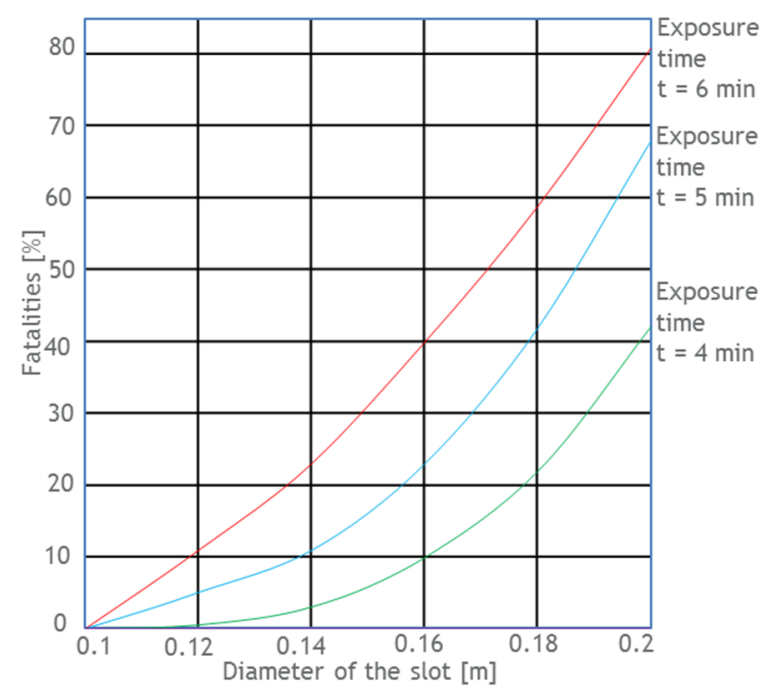

Fig. 2. Percentage of fatalities according to time of exposure for the gas pipeline at the pressure of $1.5 \mathrm{MPa}$, own work on the basis of [16]

Rys. 2. Procent ofiar śmiertelnych w zależności od czasu ekspozycji dla gazociągu o ciśnieniu 1,5 MPa, opracowano na podstawie [16] 
With the increase in the diameter of the gap and the time of exposure to thermal radiation, the number of fatalities increases. For example, with a gap of $0.2 \mathrm{~m}$ and the radiant exposure time of 6 minutes, the percentage of deaths among people exposed to heat radiation increases to more than $80 \%$.

From the above it follows that it is necessary to avoid the location of, particularly, high and medium pressure pipelines in places of human habitats. Of course, in many cases it is not possible, then materials which have a small crack propagation should be used, so that in case of breakage the gap will be small which will result in less thermal radiation.

\section{Conclusion}

In recent years, due to the growing residential areas, the length of the gas pipelines is increasing, and the probability of their failure also increases. The observed development of the gas supply network does not protect against the failure occurrence of the gas network. Safety assessment in the operation of gas supply system may contribute to reducing the potential consequences of undesirable events. The randomness of the occurrence of failure causes that conducting research related to the operation of the gas network is quite difficult and complex, first of all taking into account available operational data. It should also be noted that the escaping of natural gas can cause a threat to the environment.

In spite of the increase of safety-related procedures for the gas network functioning, gas network failures are still recorded, as presented in the examples of failures which have occurred recently, and often pose a serious threat to human health and life.

Therefore, as gas network forms a complex system and it is characterized by the unpredictability and randomness of failure occurrence, it involves proper analysis of its functioning. As gas companies are obliged to supply gas in reliable and safe way to the recipients, it is therefore appropriate to develop new research methods that will minimize the likelihood of gas pipeline failures and reduce their impact if the failure has already occurred. Such approach will be helpful in performing assessment of proper functioning of the gas systems.

\section{Literature}

[1] Dieckhoener C., Lochner S., Lindenberger D.: Simulating the Effects of European Natural Gas Infrastructure Developments, Oil Gas-European Magazine, 36(4) 2010, pp. 174-185.

[2] Dietrich A., Migracja gazu związana z nieszczelnością dystrybucyjnej sieci gazowej. Nafta-Gaz, 2016, nr 1, s. 40-44, DOI:10.18668/NG2016.01.05. 
[3] Dyrektywa Parlamentu Europejskiego i Rady 2009/73/WE z dnia 13 lipca 2009 r. dotycząca wspólnych zasad rynku wewnętrznego gazu ziemnego.

[4] European Gas pipeline Incident data Group (EGIG), 5-9 ${ }^{\text {th }}$ Reports of the European Gas Pipeline Incident Data Group (period 1970-2013). Doc. No EGIG 14.R.0403, 11.R.0402, 08.TV-B.0502，05.R.0002，02.R.0058，Amsterdam 2002, 2005, 2008, $2011,2015$.

[5] European Gas pipeline Incident data Group (EGIG): Report of Study Group 3.4. A Guideline "Using or Creating Incident Databases for Natural Gas Transmission Pipelines", Amsterdam 2006, The Netherlands.

[6] https://wiadomosci.wp.pl/rozszczelnienie-gazociagu-w-lesznie-ewakuacjamieszkancow-6027391890547841a [access 10.2016].

[7] https://www.tvn24.pl/pomorze,42/juszkowo-wybuch-zniszczyl-ich-dom-rodzinyczekaja-na-pomoc, 710660.html [access 10.2016].

[8] International Association of Oil \& Gas Producers (OGP): Health and Safety data reporting system user guide - 2011 data (May 2013).

[9] International Association of Oil \& Gas Producers (OGP): Operating Management System Framework for controlling risk and delivering high performance in the oil and gas industry (Jun 2014).

[10] International Association of Oil \& Gas Producers (OGP): Risk assessment data directory. Report No. 434-7, March 2010.

[11]Majid, Z.A., Mohsin, R., Yaacob, Z., Hassan, Z.: Failure analysis of natural gas pipes, (2010) Engineering Failure Analysis, 17 (4), pp. 818-837.

[12]Rak J.: Metoda planowania remontów sieci wodociągowej na przykładzie miasta Krosna (Method of the water supply network planning repair on the example of the Krosno city), Czasopismo Inżynierii Lądowej, Środowiska i Architektury - Journal of Civil Engineering, Environment and Architecture, JCEEA, t. XXXI, z. 61 (1/14), 2014, s. 225-232. DOI:10.7862/rb.2014.15.

[13]Rak J.R.: Propozycja oceny dywersyfikacji objętości wody w sieciowych zbiornikach wodociągowych (The proposal of diversyfication assessment of water volume in water supply network tanks). Czasopismo Inżynierii Lądowej, Środowiska i Architektury - Journal of Civil Engineering, Environment and Architecture, JCEEA, 2015, No 1, pp. 339-349. DOI:10.7862/rb.2015.23.

[14]Rak J., Pietrucha-Urbanik K. New directions for the protection and evolution of water supply systems - smart water supply. Czasopismo Inżynierii Lądowej, Środowiska i Architektury - Journal of Civil Engineering, Environment and Architecture, JCEEA, 2015, No z. 3/I, pp. 365-373. DOI:10.7862/rb.2015.121.

[15] Rozporządzenie Parlamentu Europejskiego i Rady (WE) nr 713/2009 z dnia 13 lipca 2009 r. ustanawiające Agencję ds. Współpracy Organów Regulacji Energetyki ACER.

[16]Rusin A., Stolecka K.: Poważne uszkodzenia gazociągów i ich skutki (Serious damage to pipelines and their effects). Rynek Energii, 2009, nr 6, s. 97-102.

[17] Shalaby, H.M., Riad, W.T., Alhazza, A.A., Behbehani, M.H.: Failure analysis of fuel supply pipeline, Engineering Failure Analysis, 13 (5)2006, pp. 789-796. 
[18] Tchórzewska-Cieślak B., Rak J., Analiza modernizacji remontów dystrybucyjnej sieci gazowej na przykładzie miasta Rzeszowa (Analysis of modernization and repaired distributive gas systems based on the example of the city of Rzeszow). Zeszyty Naukowe Politechniki Rzeszowskiej Budownictwo i Inżynieria Środowiska, 2003, No 2, pp. 222-229.

[19] Tchórzewska-Cieślak B., Rak J., Metoda wyznaczania niezawodności podsystemu dystrybucji gazu ziemengo dla jednostek osadniczych (Method of determining the reliability of the natural gas distribution subsystem for settlement units). Gaz, Woda i Technika Sanitarna, 2001, No 12, pp. 222-229.

[20]Tchórzewska-Cieślak B., Rak J., Ryzyko w systemie zaopatrzenia w gaz ziemny (Risk in natural gas supply system). Zeszyty Naukowe Politechniki Rzeszowskiej Budownictwo i Inżynieria Środowiska, 2003, No 2, pp. 231-242.

[21] Tchórzewska-Cieślak B.: Method of assessing of risk of failure in water supply system. European safety and reliability conference (ESREL), Risk, reliability and societal safety, Taylor \& Francis, 2007, vol. 2, pp. 1535-1539.

[22]UOKiK, http://www.ure.gov.pl/portal/pdb/459/4588/2011.html [access 10.2016].

[23] Urbanik M., Tchórzewska-Cieślak B.: Ecological aspects of the natural gas use, Czasopismo Inżynierii Lądowej, Środowiska i Architektury - Journal of Civil Engineering, Environment and Architecture, JCEEA, t. XXXII, z. 62(1/15), s. 409-417. DOI:10.7862/rb.2015.29.

[24]Urbanik M., Tchórzewska-Cieślak B.: Podstawy analizy niezawodności funkcjonowania instalacji wykorzystujących gaz ziemny, Czasopismo Inżynierii Lądowej, Środowiska i Architektury - Journal of Civil Engineering, Environment and Architecture, JCEEA, t. XXXII, z. 62 (1/15), s. 419-431. DOI:10.7862/rb.2015.30.

[25] Witek M. Ryzyko eksploatacji sieci przesyłowej gazu. Gaz, Woda i Technika Sanitarna (Exploitation risk in gas transmission grids), 2001, $\mathrm{Nr} 1, \mathrm{~s} .19-23$.

\section{WYBRANE ZAGADNIENIA DOTYCZĄCE BEZPIECZEŃSTWA DOSTAW GAZU}

\section{Streszczenie}

Bezpieczeństwo dostaw gazu jest znacznie uzależnione od wystąpienia awarii. Sieci gazowe stanowią duże aktywa zakładów gazowych, dlatego kluczowe znaczenie ma dla nich utrzymanie bezpiecznego i niezawodnego funkcjonowania infrastruktury gazowej. Katastrofa spowodowana wybuchem gazu może nieść za sobą bardzo duże straty materialne i ludzkie. Przedstawione podejście można wykorzystać do opisania strat wynikających $\mathrm{z}$ awarii sieci gazowej. Może również dostarczyć informacji na temat oceny systemów dostaw gazu w odniesieniu do kosztów i strat związanych z awarią sieci gazowych. Analiza oparta była na rzeczywistych danych uzyskanych na podstawie eksploatacji sieci gazowej.

Słowa kluczowe: sieć gazowa, straty gazu, funkcjonowanie sieci gazowej, awaria sieci gazowej

Przestano do redakcji: 15.11.2016 $r$.

Przyjęto do druku: 15.06.2017 r. 